\title{
Kelola
}

Jurnal Manajemen Pendidikan

Magister Manajemen Pendidikan

e-ISSN 2549-9661

FKIP Universitas Kristen Satya Wacana

jurnalkelola@gmail.com

Volume: 5, No. 1, Januari-Juni 2018

Halaman: 24-36

\section{Evaluasi Kinerja Guru Bersertifikasi Dengan Model Charlotte Danielson}

\author{
Wara Hapsari Oktriany \\ Magister Manajemen Pendidikan \\ Universitas Kristen Satya Wacana \\ oktrianywara@gmail.com \\ Bambang Suteng Sulasmono \\ Magister Manajemen Pendidikan \\ Universitas Kristen Satya Wacana \\ bambang.sulasmono@staff.uksw.edu \\ Ade Iriani \\ Magister Manajemen Pendidikan \\ Universitas Kristen Satya Wacana \\ ade.iriani@staff.uksw.edu
}

\begin{abstract}
This study aims to evaluate the performance of certified teachers in SMP Negeri 3 Salatiga in the domain: (1) planning and preparation of learning, (2) class management, (3) learning process, and (4) professional teacher responsibility. This research is an evaluative research using Charlotte Danielson Model, with simple qualitative and quantitative method. The subjects were five teachers of SMP Negeri 3 Salatiga who have been certified educators. Data collection through interviews, observation, and document study. Moderate data collection instruments include teacher performance assessment rubric, interview guides, and questionnaires. The data validity test is done by source and technique triangulation. The results of this study: (1) the certified teacher performance in preparing and planning of learning is included in the good category, (2) the certified teacher performance in managing the classes included in the good category; (3) the certified teacher performance in the learning process included in either category, and (4) the certified teacher performance in their professional responsibilities is categorized as good enough, due to the lack of teachers' efforts to develop themselves.
\end{abstract}

Keywords: Certified Teacher, Charlotte Danielson Model, Performance Evaluation

\section{Article Info}




\section{PENDAHULUAN}

Upaya meningkatkan mutu pendidikan telah dan terus dijalankan oleh pemerintah melalui berbagai kebijakan. Dua kebijakan yang menyangkut kualitas tenaga pendidik di Indonesia adalah kebijakan peningkatan kualifikasi, kompetensi, dan profesionalisme tenaga pendidik dan kependidikan, dan kebijakan peningkatkan kesejahteraan tenaga pendidik melalui sertifikasi (Kunandar, 2007: 6-7). Kedua kebijakan ini amat penting karena tenaga pendidik atau guru mempunyai peranan yang besar dan strategis dalam proses pendidikan. Gurulah yang berada di barisan terdepan dalam pelaksanaan pendidikan, langsung berhadapan dengan peserta didik untuk mentransfer ilmu pengetahuan dan teknologi sekaligus mendidik dengan nilainilai positif melalui bimbingan dan keteladanan. $\mathrm{Di}$ tangan gurulah akan dihasilkan peserta didik yang berkualitas, baik secara akademis, skill (keahlian), kematangan emosional, dan moral serta spiritual. Dengan demikian akan dihasilkan generasi masa depan yang siap hidup dengan tantangan zamannya. Oleh karena itu, diperlukan seorang guru yang mempunyai kualifikasi, kompetensi, dan dedikasi yang tinggi dalam menjalankan tugas profesionalnya. (Kunandar, 2007:40).

Lebih lanjut, guna meningkatkan kesejahteraan dan kualitas kinerja tenaga pendidik, pemerintah menetapkan kebijakan sertifikasi bagi tenaga pendidik. Sertifikasi adalah proses pemberian sertifikat kepada sesuatu objek tertentu (orang, barang, atau organisasi tertentu) yang menandakan bahwa objek tersebut layak menurut kriteria atau standar tertentu (Payong, 2011: 68). Dengan demikian maka sertifikasi Guru adalah proses pemberian sertifikat pendidik kepada guru (Suyatno, 2007: 2). Secara lebih lengkap Muslich (2007: 2) mengemukakan bahwa sertifikasi guru adalah proses pemberian sertifikat pendidik kepada guru yang telah memenuhi persyaratan tertentu, yaitu memiliki kualifikasi akademik, kompetensi, sehat jasmani dan rohani, serta memiliki kemampuan untuk mewujudkan tujuan pendidikan nasional yang disertai dengan peningkatan kesejahteraan yang layak. Sedang dalam Undang Undang No 14 tahun 2005 dinyatakan bahwa sertifikat pendidik diberikan kepada guru yang telah memenuhi standar profesi guru. Sertifikasi pendidik adalah proses pemberian sertifikat pendidik untuk guru dan dosen. Sertifikasi pendidik adalah bukti formal sebagai pengakuan yang diberikan kepada guru dan dosen sebagai tenaga profesional. Oleh karena itu sertifikat pendidik adalah sertifikat yang ditanda tangani oleh perguruan tinggi penyelenggara sertifikasi sebagai bukti formal pengakuan profesionalitas guru yang diberikan kepada guru sebagai tenaga professional (Suyatno, 2007:2). Program sertifikasi guru itu sendiri mempunyai beberapa tujuan diantaranya adalah untuk (a) menentukan kelayakan guru dalam melaksanakan tugas sebagai agen pembelajaran dalam rangka mewujudkan tujuan pendidikan nasional, (b) meningkatkan mutu proses dan hasil pendidikan, (c) meningkatkan martabat guru, (d) meningkatkan profesionalisme guru, dan (e) meningkatkan kesejahteraan guru (Payong, 2011: 76-77). Sertifikasi bertujuan untuk meningkatkan kesejahteraan tenaga pendidik. Dengan meningkatnya kesejahteraan diharapkan tenaga pendidik bisa meningkatkan kinerja mengajar mereka, yang akan berdampak pada meningkatnya mutu pembelajaran dan mutu pendidikan secara berkelanjutan (Suyatno, 2007:24).

Dari beberapa definisi di atas, dapat disimpulkan bahwa sertifikasi guru merupakan proses pemberian sertifikat pendidik kepada guru yang telah memenuhi standar profesi guru serta memiliki kemampuan untuk mewujudkan tujuan pendidikan nasional yang disertai dengan peningkatan kesejahteraan yang layak, sehingga dapat meningkatkan kualitas 
pendidikan di Indonesia dan profesionalitas guru. Guru bersertifikasi dengan demikian adalah tenaga pendidik yang telah memenuhi persyaratan standar profesi guru serta memiliki kemampuan untuk mewujudkan tujuan pendidikan nasional dan oleh karena itu kemudian menerima sertifikat pendidik dari lembaga yang berwenang. Guru bersertifikasi diharapkan dapat meningkatkan kinerja mengajar mereka yang pada gilirannya akan berdampak pada meningkatnya mutu pembelajaran dan mutu pendidikan secara berkelanjutan.

Tentang kinerja Wirawan (2009:5) berpendapat bahwa kinerja adalah keluaran yang dihasilkan oleh fungsi-fungsi atau indikator-indikator suatu pekerjaan atau suatu profesi dalam waktu tertentu. Suatu pekerjaan atau profesi mempunyai sejumlah fungsi atau indikator yang dapat digunakan untuk mengukur hasil pekerjaan tersebut. Sedang Bangun (2012, 231) mendefinisikan kinerja sebagai hasil pekerjaan yang dicapai seseorang berdasarkan persyaratan-persyaratan pekerjaan (job requirement). Suatu pekerjaan mempunyai persyaratan tertentu untuk dapat dilakukan dalam mencapai tujuan (standar pekerjaan). Mangkunegara (dalam Widodo, 2015:131) menyatakan bahwa istilah kinerja berasal dari kata job performance atau actual performance (prestasi kerja atau prestasi sesungguhnya yang dicapai oleh seseorang) yaitu hasil kerja secara kualitas dan kuantitas yang dicapai oleh seorang pegawai dalam melaksanakan tugasnya sesuai dengan tanggung jawab yang diberikan kepadanya. Pendapat Wirawan, Bangun, dan Mangkunegara mempunyai persamaan, yaitu mereka mengemukakan bahwa kinerja adalah hasil pekerjaan seseorang yang dicapai dalam melaksanakan pekerjaan atau tugas yang telah diberikan kepadanya sesuai dengan persyaratan ataupun aturan yang ada. Berbeda dengan pendapat diatas, Wibowo $(2013,81)$ mengemukakan bahwa kinerja merupakan suatu proses tentang bagaimana pekerjaan berlangsung untuk mencapai hasil kerja. Marwansyah (2010:228) juga mendefinisikan kinerja sebagai pencapaian / prestasi seseorang berkenaan dengan tugas-tugas yang dibebankan kepadanya. Kinerja dapat juga dipandang sebagai perpaduan dari hasil kerja (apa yang harus dicapai seseorang) dan kompetensi (bagaimana seseorang mencapainya). Dari beberapa rumusan pengertian kinerja di atas, dapat disimpulkan bahwa kinerja merupakan hasil kerja yang dapat dicapai oleh seseorang sesuai dengan wewenang dan tanggung jawab masingmasing dalam pencapaian suatu tujuan tanpa melanggar aturan yang ada.

Mengenai kinerja Guru patut dicatata bahwa Guru adalah seorang pendidik professional yang bertugas mendidik, mengajar, membimbing, mengarahkan, melatih, menilai, dan mengevaluasi peserta didik pada pendidikan anak usia dini jalur pendidikan formal, pendidikan dasar, dan pendidikan menengah (Priatna, 2013:3). Hasil yang dicapai secara optimal dalam bentuk lancarnya proses belajar siswa, dan berujung pada tingginya perolehan atau hasil belajar siswa, semuanya merupakan cerminan kinerja seorang guru. Dalam menjalankan peran dan fungsinya pada proses pembelajaran di kelas, kinerja guru dapat terlihat pada kegiatannya merencanakan, melaksanakan, dan mengevaluasi proses pembelajaran yang intensitasnya dilandasi oleh sikap moral dan profesional seorang guru (Uno, 2012: 65). Undang Undang No. 14 Tahun 2005 tentang Guru dan Dosen bab IV pasal 20 (a) menyatakan bahwa standar prestasi kerja guru dalam melaksanakan tugas keprofesionalannya, guru berkewajiban merencanakan pembelajaran, melaksanakan proses pembelajaran yang bermutu serta menilai dan mengevaluasi hasil pembelajaran. Tugas pokok guru yang diwujudkan dalam kegiatan belajar mengajar merupakan bentuk 
kinerja guru. Dari beberapa pengertian di atas maka dapat disimpulkan bahwa kinerja guru merupakan hasil pekerjaan atau prestasi kerja yang dilakukan oleh seorang guru berdasarkan kemampuan mereka untuk mengelola kegiatan belajar mengajar, yang meliputi perencanaan pembelajaran, pelaksanaan pembelajaran, evaluasi pembelajaran dan membina hubungan antar pribadi (interpersonal) dengan siswanya.

Kebijakan sertifikasi Guru sudah dilegalkan dalam Undang-undang Nomor14 tahun 2005 tentang Guru dan Dosen, serta sudah berjalan kurang lebih selama 10 tahun sejak tahun 2007 hingga tahun 2017. Namun pelaksanaan di lapangan ternyata belum sesuai harapan, karena masih banyak dijumpai guru bersertifikasi yang kualitas kinerjanya justru diragukan. Hal itu bisa dipahami karena berbagai kajian tentang kebijakan publik, termasuk kebijakan publik dalam bidang pendidikan menunjukkan bahwa selalu terdapat kesenjangan implementasi atau implementation gap dalam proses kebijakan (Rosli \& Rossi, 2014; Effiong, 2013; Iqbal Ahmad et.all, 2012; Center for International Private Enterprise and Global Integrity, 2012; .Makinde, 2008;). Menurut Centre for International Private Enterpise \& Global Integrity (CIPE-GI, 2012) "implementation gap is the difference between laws on the books and how they are carried out in practice". Dengan perkataan lain selalu terdapat kesenjangan antara maksud kebijakan itu sendiri dengan apa yang terwujud dalam pelaksanaan kebijakan yang bersangkutan (bandingkan misalnya dengan Sulasmono \& Tri Sulistyowati, 2016; Sasadara, Sulasmono dan Ade Iriani, 2017)

Khusus ihwal kebijakan sertifikasi Guru, penelitian Khodijah (2013) tentang kinerja Guru Madrasah dan Guru Pendidikan Agama Islam pasca sertifikasi di Sumatera Selatan, menunjukkan bahwa tidak terdapat perbedaan dalam kinerja guru setelah menerima tunjangan profesional dalam aspek
(1) rencana pembelajaran, pelaksanaan, dan asesmen; (2) antara mereka yang tinggal di daerah pedesaan dan di daerah perkotaan; dan (3) antara mereka yang lulus melalui portofolio dan yang melalui PLPG. Dengan kata lain kinerja guru bersertifikasi masih di bawah standar minimum kinerja. Selanjutnya penelitian Kurniawan (2011) berjudul "Implementasi Kebijakan Sertifikasi Guru dalam Rangka Meningkatkan Profesionalitas Guru di Kota Yogyakarta" menyimpulkan bahwa jika dilihat dari segi dampak kebijakan sertifikasi, belum ada peningkatan profesionalitas guru secara signifikan. Sikap para guru dalam menjalankan kebijakan sertifikasi terlihat hanya mengejar kesejahteraan semata, sementara mutu pengajaran kurang mendapat perhatian. Sedang penelitian Yusrizal, dkk (2011) dengan judul "Evaluasi Kinerja Guru Fisika, Biologi, dan Kimia SMA yang sudah lulus sertifikasi" menunjukkan bahwa kinerja guru Fisika, Biologi, dan Kimia SMA yang sudah lulus sertifikasi dan sudah menerima tunjangan belum seluruhnya berkinerja tinggi. Sementara itu penelitian Amat Jaedun (2009) dengan judul "Evaluasi Kinerja Guru Bersertifikat Profesional" juga menunjukkan bahwa kinerja guru yang telah disertifikasi (guru profesional) tidak menjadi lebih baik bila dibandingkan dengan kinerja guru sebelum disertifikasi. Kinerja guru menurun karena merasa tidak lagi dinilai, dan tidak ada sanksi setelah mendapatkan sertifikasi. Oleh karena itulah perlu dilakukan evaluasi terhadap kinerja guru yang telah disertifikasi tersebut secara berkelanjutan.

Berbeda dengan hasil-hasil penelitian di atas, penelitian Faiza (2015) dengan judul “ Evaluasi Implementasi Kebijakan Sertifikasi Guru di Sekolah Dasar Negeri 13 Kota Pontianak" menunjukkan bahwa guru sudah dapat dikatakan layak dan dalam pelaksanaan belajar-mengajar, guru dapat menguasai materi pada saat proses belajar mengajar serta 
Kelola: Jurnal Manajemen Pendidikan, Vol. 5, No. 1, Januari-Juni 2018

jika ada nilai siswa-siswi yang kurang dari KKM guru bersangkutan berusaha mengadakan remedial dan menganalisis materi mana yang dianggap sulit oleh siswa-siswi dan menambah nilai yang ada dengan nilai harian mereka agar bisa mencapai KKM yang telah ditetapkan. Namun, hanya sedikit sekali guru yang menggunakan perangkat IT dalam proses belajar mengajar serta nilai siswa belum naik secara signifikan dilihat dari nilai kelulusan siswa setiap tahunnya setelah adanya kebijakan sertifikasi. Sedang penelitian Setiawan, Setyorini, dan Yushita (2009) yang berjudul "Audit Kinerja Guru Akuntansi Bersertifikat di SMK Negeri 2 Kutoarjo Purworejo" menunjukkan bahwa sertifikasi pendidik dapat meningkatkan kinerja guru dalam menjalankan tugas profesinya sebagai guru. Kinerja guru akuntansi bersertifikat di SMK Negeri 2 Kutoarjo ditinjau dari pelaksanaan kompetensi guru menunjukkan dalam kategori cukup/sedang yaitu sebesar $64,7 \%$ dan yang menunjukkan kategori baik sebesar 32,3\%. Sementara penelitian Tethys Arsynta (2015) dengan judul "Kinerja Guru Bersertifikat Profesi dalam Pembelajaran di SMK Negeri se-Kota Magelang” menyimpulkan bahwa (1) kinerja guru bersertifikat profesi dalam perencanaan pembelajaran dikategorikan baik; (2) kinerja guru bersertifikat profesi dalam pelaksanaan pembelajaran dikategorikan baik, (3) kinerja guru bersertifikat profesi dalam pelaksanaan pembelajaran dengan sub indikator pengelolaan kelas dikategorikan cukup baik, sub indikator penggunaan metode pembelajaran dikategorikan cukup baik, dan sub indikator penggunaan media dan sumber belajar dikategorikan cukup baik; (4) kinerja guru bersertifikat profesi dalam evaluasi pembelajaran dikategorikan baik, evaluasi pembelajaran dengan sub indikator pendekatan dan jenis evaluasi pembelajaran dikategorikan cukup baik, sub indikator penyusunan alat evaluasi pembelajaran dikategorikan baik, dan sub indikator penggunaan hasil evaluasi pembelajaran dikategorikan sangat baik.

Berdasarkan kajian teoritis dan berbagai temuan hasil penelitian yang saling bertentangan di atas, maka penulis tertarik untuk mengevaluasi kinerja mengajar guru bersertifikasi di SMP Negeri 3 Salatiga dengan menggunakan model Charlotte Danielson.

Evaluasi kinerja guru atau penilaian kinerja guru adalah penilaian yang dirancang untuk mengidentifikasi kemampuan guru dalam melaksanakan tugasnya melalui pengukuran penguasaan kompetensi yang ditunjukkan dalam unjuk kerjanya (Priatna, 2013: 1). Pentingnya penilaian kompetensi guru terutama terkait pertimbangan bahwa penguasaan kompetensi dan penerapan pengetahuan serta keterampilan guru, sangat menentukan tercapainya kualitas proses pembelajaran atau pembimbingan peserta didik. Berdasarkan Peraturan Menteri Negara Pendayagunaan Aparatur Negara dan Reformasi Birokrasi Nomor 16 tahun 2009 tentang jabatan Fungsional Guru dan Angka Kreditnya, Penilaian Kinerja Guru untuk guru mata pelajaran dan guru kelas meliputi kegiatan sebagai berikut: (1) menyusun kurikulum pembelajaran pada satuan pendidikan, (2) menyusun silabus pembelajaran, (3) menyusun rencana pelaksanaan pembelajaran, (4) melaksanakan kegiatan pembelajaran, (5) menyusun alat ukur / soal sesuai mata pelajaran, (6) menilai dan mengevaluasi proses dan hasil belajar pada mata pelajaran yang diampunya, (7) menganalisis hasil penilaian pembelajaran, (8) melaksanakan pembelajaran/perbaikan dan pengayaan dengan memanfaatkan hasil penilaian dan evaluasi, (9) menjadi pengawas penilaian dan evaluasi terhadap proses dan hasil belajar tingkat sekolah dan nasional, (10) membimbing guru pemula dalam program induksi, (11) membimbing siswa dalam kegiatan ekstrakurikuler proses pembelajaran, (12) melaksanakan pengembangan diri, (13) 
Evaluasi Kinerja Guru Bersertifikasi Dengan Model Charlotte Danielson | Wara H. Oktriany, dkk.

melaksanakan publikasi ilmiah, dan (14) membuat karya inovatif. Selain meliputi kegiatan merencanakan dan melaksanakan pembelajaran, mengevaluasi dan menilai serta menganalisis hasil penilaian terkait tugas pembelajaran, penilaian kinerja guru juga melakukan penilaian terhadap 4 domain kompetensi yang harus dimiliki oleh guru sesuai dengan peraturan menteri pendidikan nasional nomor 16 tahun 2007 tentang standar kualifikasi akademik dan kompetensi guru. Pengelolaan pembelajaran tersebut mensyaratkan guru memiliki kompetensi yang dikelompokkan ke dalam empat domain kompetensi yaitu pedagogik, kepribadian, sosial, dan profesional. Dapat disimpulkan bahwa evaluasi kinerja guru bersertifikasi adalah evaluasi terhadap kinerja guru bersertifikasi dalam merencanakan, melaksanakan dan mengevaluasi hasil belajar siswa sebagai dampak dari proses belajar mengajar yang dikelolanya.

Peneliti memilih menggunakan model Charlotte Danielson, karena model ini sudah diterapkan di beberapa sekolah di Amerika Serikat dan dapat membantu meningkatkan kualitas guru dalam mengajar. Dengan model ini guru diharapkan dapat menilai kinerja guru dalam mengajar dan juga dapat memperbaiki kinerja mereka menjadi lebih baik. Model mengajar Charlotte Danielson dikembangkan berdasarkan Praxis Series. Praxis Series adalah standar professional yang telah memiliki dampak besar terhadap program pendidikan guru secara nasional (serta pertumbuhan dan pengembangan professional guru berkelanjutan). Praxies Series menilai perkembangan individu sesuai dengan tiga langkah untuk menjadi guru. Ketiga bidang assesmen ini adalah Asesmen Keterampilan Akademis : memasuki program pendidikan guru (Praxis I), Asesmen Mata Pelajaran: lisensi untuk masuk profesi (Praxis II), dan Asessmen Kinerja sekolah (Praxis III). Di dalam Praxis III inilah yang melibatkan asesmen dari keterampilan mengajar sebenarnya yang terbagi dalam 4 domain mengajar Danielson (Parkay, 2011:28-29).

Empat domain mengajar Charlotte Danielson terdiri dari persiapan dan perencanaan pembelajaran, pengelolaan ruang kelas, pembelajaran, dan tanggung jawab profesional. Empat domain ini memiliki 22 komponen dan terbagi lagi menjadi beberapa elemen untuk lebih memperjelas pemahaman kita tentang apa arti mengajar (Danielson, 2007 :1). Domain 1 yaitu persiapan dan perencanaan pembelajaran. Didalam domain ini adalah langkah pertama dalam mengajar yang efektif, yaitu dengan adanya perencanaan dan persiapan yang efektif. Domain perencanaan, melibatkan semua pekerjaan yang dilakukan sebelum pembelajaran yang sebenarnya terjadi. Domain 1 terlihat pada semua komponen yang relevan dari perencanaan dan persiapan yang membantu guru saat memasuki kelas dengan keyakinan dan menginspirasi kepercayaan siswa. Perencanaan dan persiapan yang melibatkan lebih dari hanya menulis kegiatan hari itu di kalender perencanaan. Domain 1 berisi semua berbagai aspek perencanaan, termasuk pentingnya pengetahuan siswa dan sumber daya yang tersedia. Tanpa mengetahui tentang siswa, guru tidak bisa mendesain pembelajaran yang bermakna dan sesuai. Tanpa mengetahui sumber daya apa tersedia dan sesuai untuk digunakan dalam perencanaan dan instruksi, seorang guru dibatasi dengan visi sempit dari pengajaran. Tentu saja, seorang guru harus memiliki pengetahuan materi ajar dan pengetahuan strategi pembelajaran agar menjadi efektif. Pengetahuan ini digunakan untuk memilih hasil pengajaran, untuk mendesain pembelajaran koheren, dan merencanakan untuk penilaian yang bermakna (Danielson, 2007: 26 - 28).

Domain 2 yaitu pengelolaan ruang kelas. Di dalam domain ini para pendidik harus selalu mengingat bahwa guru favorit adalah 
guru yang memiliki rasa humor, membuat pembelajaran yang relevan, memberikan pujian tanpa syarat, dan membuat siswa merasa aman, dihargai dan dihormati. Para pendidik juga harus mengingat bahwa ada juga guru yang mengkritik siswa, meremehkan usaha siswa, dan menciptakan suasana ketakutan. Setiap sikap dan perilaku guru ini akan dikenang lama setelah siswa tersebut dewasa (Danielson, 2007: 28-29).

Domain 3 adalah pembelajaran. Dalam domain 3 inilah pengajaran yang sebenarnya. Ini mencakup segala sesuatu yang guru lakukan agar pembelajaran siswa serta kemampuan siswa dapat diterapkan pada pembelajaran yang akan datang. Penyampaian pembelajaran menempatkan keakraban guru dengan karakteristik tingkat usia siswa, pengetahuan tentang setiap siswa di setiap kelas, menggunakan beberapa strategi pengajaran, dan pembentukan gerakan tubuh sesuai dengan kegiatan dalam pelajaran. Ini adalah alat setiap guru yang memungkinkan guru untuk memotivasi setiap siswa untuk mencapai potensi diri nya. Komponen domain ini melaksanakan perencanaan yang matang bahwa guru telah melakukannya dalam Domain 1, memanfaatkan lingkungan belajar yang aman yang ditetapkan pada Domain 2, dan mengubah semua komponen yang telah mendahului ajaran ini ke dalam materi ajar yang mudah dipahami siswa. Ketika materi ajar disajikan, guru juga terus memantau dan mengevaluasi tanggapan siswa untuk menentukan apakah siswa memahami apa yang diajarkan. Penilaian formal dan informal adalah berkelanjutan dan menyediakan data berharga yang menginformasikan kapan guru dan bagaimana menyesuaikan pengajaran untuk kebutuhan siswa (Danielson, 2007: 29 30).

Domain 4 adalah tanggung jawab profesional guru. Tanggung jawab profesional, berfokus pada tindakan yang terjadi setelah proses pembelajaran. Dengan adanya pengalaman mengajar, guru memahami nilai refleksi untuk meningkatkan dan merencanakan instruksi pembelajaran berikutnya. Guru-guru yang efektif mengevaluasi kekuatan dan kelemahan dari pembelajaran yang telah dilakukan, mengacu pada catatan refleksi mereka untuk memperbaiki pengajaran mereka. Selain itu, guru profesional berkomunikasi dan berkolaborasi dengan orang tua murid dan kolega. Guru yang efektif membuat orang tua dan keluarga terlibat dalam program pembelajaran melalui konferensi dijadwalkan, panggilan telepon, menulis catatan, dan mengundang orang tua datang ke sekolah. Selain itu, guru mencoba mendukung hubungan dengan satu sama lain dan berbagi dalam perencanaan pembelajaran. Mereka menerima umpan balik dan terus berupaya membuat keputusan berdasarkan standar profesionalisme yang tinggi (Danielson, 2007: 30-31).

Penelitian ini bertujuan untuk mengevaluasi kinerja guru bersertifikasi di SMP Negeri 3 Salatiga dalam (1) merencanakan dan mempersiapkan pembelajaran, (2) mengelola kelas, (3) berinteraksi dengan siswa saat pembelajaran berlangsung, dan (4) dalam menunjukkan tanggung jawab profesionalnya sebagai seorang guru. Hasil penelitian ini diharapkan dapat memberi gambaran tentang kualitas kinerja guru bersertifikasi, dan jika diperlukan dapat menjadi acuan dalam upaya peningkatan kinerja guru bersertifikasi maupun para pihak yang relevan yaitu Kepala Sekolah dan Pengawas Sekolah.

\section{METODE PENELITIAN}

Penelitian ini merupakan penelitian evaluatif. Penelitian evaluatif yang dilakukan peneliti termasuk jenis penelitian evaluatif kinerja sumber daya manusia. Penelitian ini bertujuan untuk melaksanakan evaluasi dan menggambarkan data yang berupa keterangan 
Evaluasi Kinerja Guru Bersertifikasi Dengan Model Charlotte Danielson | Wara H. Oktriany, dkk.

dan pernyataan yang ada tentang kinerja guru bersertifikasi. Penelitian dilakukan terhadap 5 (lima) orang guru kelas VII bersertifikasi yang bekerja di SMP Negeri 3 Salatiga.

Pendekatan penelitian yang digunakan adalah pendekatan kuantitatif sederhana dan kualitatif. Pendekatan kuantitatif menggunakan teknik pengumpulan data berupa angket dan observasi dengan instrument kuesioner dan Rubrik Penilaian Kinerja Guru yang merupakan terjemahan dari rubrik penilaian kinerja guru Model Charlotte Danielson. Selanjutnya untuk mencek dan memperbaiki kebenaran data dari kuesioner tersebut dilakukan pengumpulan data kualitatif dengan teknik wawancara dan studi dokumen.

Subyek penelitian meliputi kepala sekolah, wakil kepala sekolah, guru bersertifikasi, dan siswa di SMP Negeri 3 Salatiga. Peneliti memberikan kuesioner kepada siswa dan rubrik penilaian kinerja guru bersertifikasi kepada wakil kepala sekolah. Selain itu peneliti melakukan wawancara dengan guru bersertifikasi dan kepala sekolah serta observasi proses mengajar para guru bersertifikasi. Data hasil kuesioner siswa dan data hasil pengisian rubrik penilaian kinerja guru oleh Wakasek dibandingkan dengan hasil wawancara guru, siswa, dan Kepala Sekolah. Selanjutnya data-data tersebut dibandingkan dengan data hasil observasi dan studi dokumen, sehingga data yang diperoleh benarbenar valid.

\section{HASIL PENELITIAN DAN PEMBAHASAN}

\section{Hasil Penelitian}

Persiapan dan Perencanaan Pembelajaran (DOMAIN 1). Hasil penelitian menyatakan bahwa kelima guru yang diteliti telah melakukan persiapan dan perencanaan pembelajaran dengan baik.

Tabel 1. Hasil Evaluasi Kinerja Guru pada Domain 1 Persiapan dan Perencanaan pembelajaran

\begin{tabular}{lccccc}
\hline \multicolumn{1}{c}{ KOMPONEN DOMAIN 1 } & ZM & JH & TA & DW & SM \\
\hline $\begin{array}{l}\text { Menunjukkan pengetahuan tentang standar kompetensi dan } \\
\text { strategi pembelajaran }\end{array}$ & 3 & 3 & 4 & 3 & 3 \\
\hline Menunjukkan pengetahuan tentang karakteristik peserta didik & 3 & 3 & 3 & 3 & 3 \\
\hline Pemilihan tujuan pembelajaran & 4 & 4 & 3 & 3 & 3 \\
\hline $\begin{array}{l}\text { Menunjukkan pengetahuan tentang materi pembelajaran yang } \\
\text { digunakan }\end{array}$ & 3 & 4 & 4 & 3 & 3 \\
\hline Merancang pembelajaran yang logis & 4 & 4 & 3 & 3 & 3 \\
\hline Menilai pembelajaran siswa & 4 & 4 & 4 & 4 & 4 \\
\hline
\end{tabular}

Sumber: Data penelitian

Tabel di atas menunjukkan bahwa skor para Guru berada pada kategori baik dan beberapa aspek ada yang sangat baik, menurut skala evaluasi Charlotte Danielson. Dengan kata lain para guru tersebut telah mampu menetapkan tujuan dengan cermat dan menyusun langkah-langkah kegiatan pembelajaran dengan baik. Dalam pembuatan RPP guru memahami benar tentang komponen-komponen yang harus ada dalam RPP (standar kompetensi, kompetensi dasar, komponen pencapaian kompetensi, tujuan pembelajaran, alokasi waktu, metode pembelajaran, kegiatan pembelajaran, penilaian, dan sumber belajar). Namun ada beberapa aspek dalam perencanaan pembelajaran yang perlu diperbaiki yaitu perencanaan penggunaan metode pembelajaran, sumber belajar, dan media yang digunakan dalam pembelajaran. Selain itu, guru - guru tersebut belum membuat RPP sesuai dengan karakteristik siswa, jadi hanya ada satu macam RPP untuk semua siswa dimana tiap siswa memliki karakteristik yang berbeda. Materi pembelajaran ataupun tugas yang digunakan sama untuk semua 
Kelola: Jurnal Manajemen Pendidikan, Vol. 5, No. 1, Januari-Juni 2018

karakteristik anak, tidak dibedakan untuk anak yang berkemampuan rendah, sedang, ataupun tinggi.
Pengelolaan Kelas (Domain 2). Pada domain 2, semua guru mempunyai kinerja yang baik dalam mengelola kelas saat pembelajaran.

Tabel 2. Hasil Evaluasi Kinerja Guru pada Domain 2 Pengelolaan Kelas

\begin{tabular}{lccccc}
\hline \multicolumn{1}{c}{ KOMPONEN DOMAIN 2 } & ZM & JH & TA & DW & SM \\
\hline $\begin{array}{l}\text { Menciptakan suasana belajar yang diliputi dengan } \\
\text { saling menghargai dan saling berhubungan baik }\end{array}$ & 4 & 4 & 4 & 3 & 3 \\
\hline Mengembangkan budaya belajar & 4 & 4 & 3 & 3 & 3 \\
\hline Mengelola kelas & 3 & 3 & 3 & 3 & 3 \\
\hline Mengatur perilaku siswa & 3 & 3 & 4 & 3 & 3 \\
\hline Menata ruang kelas & 3 & 3 & 3 & 3 & 3 \\
\hline
\end{tabular}

Sumber: Data penelitian

Tabel 2 di atas menunjukkan bahwa skor para Guru pada aspek pengelolaan kelas berada pada kategori baik dan beberapa sub aspek ada yang sangat baik, menurut skala evaluasi Charlotte Danielson. Kinerja guru tersebut antara lain ditunjukkan oleh sikap semua guru yang selalu berusaha untuk menghargai siswa, mengembangkan budaya belajar di kelas dengan berbagai kegiatan supaya anak tidak bosan mengikuti pelajaran dikelas ataupun pada saat pembelajaran diluar kelas. Selain itu juga, guru berhasil mengatur perilaku siswa yang tidak mengikuti aturan yang ada, seperti misalnya ketika siswa tidak mengerjakan PR, maka guru meminta siswa untuk berlari keliling lapangan. Guru menggunakan tutur kata yang sopan dalam menyampaikan materi pelajaran, sehingga siswa tertarik atau menyukai guru tersebut. Karena kurikulum yang dipakai saat ini adalah kurikulum 2013, maka pembelajaran tidak selalu dilakukan didalam kelas, terkadang guru mengajak keluar kelas pada saat pembelajaran berlangsung. Siswa diminta untuk melakukan pengamatan terhadap lingkungan sekitar, diskusi dengan teman. Dengan metode pembelajaran diluar sekolah, siswa jadi tidak bosan untuk belajar sehingga mereka bisa memahami pelajaran dengan baik.

Pembelajaran (Domain 3). Pada domain 3 tentang proses pembelajaran, berdasarkan hasil rubrik wakil kepala sekolah, semua guru mempunyai kinerja baik.

Tabel 3. Hasil Evaluasi Kinerja Guru pada Domain 3 Pembelajaran

\begin{tabular}{lccccc}
\hline \multicolumn{1}{c}{ KOMPONEN DOMAIN 3 } & ZM & JH & TA & DW & SM \\
\hline Berkomunikasi dengan siswa & 3 & 3 & 3 & 3 & 3 \\
\hline Menggunakan teknik tanya jawab dan diskusi & 4 & 4 & 3 & 3 & 3 \\
\hline Melibatkan siswa dalam pembelajaran & 4 & 4 & 3 & 3 & 3 \\
\hline Memberikan umpan balik bagi siswa (penilaian) & 3 & 3 & 3 & 3 & 3 \\
\hline Menunjukkan sikap fleksibel dan responsif (cepat tanggap) & 3 & 3 & 3 & 3 & 3 \\
\hline
\end{tabular}

Sumber: Data penelitian

Tabel 3 di atas menunjukkan bahwa skor para Guru pada aspek pembelajaran berada pada kategori baik dan beberapa sub-aspek ada yang sangat baik, menurut skala evaluasi Charlotte Danielson.

Namun pada kenyataannya, berdasarkan pendapat beberapa siswa, masih ada guru yang selalu memerintahkan siswa nya untuk mengerjakan soal sedangkan hanya sedikit memberikan penjelasan. Ada pula guru yang memberikan hukuman ketika siswa tidak mengerjakan PR atau ketika remidi. Kadang kadang guru juga berbicara terlalu cepat dalam menjelaskan materi pelajaran sehingga siswa masih kurang memahami materi pelajaran tersebut. Dalam pembelajaran, guru menggunakan sistem berdiskusi baik dalam kelompok kecil maupun kelompok besar. Dengan dibuat sistem berkelompok, siswa akan berinteraksi dengan temannya. Siswa 
Evaluasi Kinerja Guru Bersertifikasi Dengan Model Charlotte Danielson | Wara H. Oktriany, dkk.

berlatih untuk bekerja sama dengan temannya.

Tanggung Jawab Profesional

(Domain 4). Pada domain 4 tentang tanggung jawab profesional, guru berkinerja cukup berdasarkan hasil rubrik.

Tabel 4. Hasil Evaluasi Kinerja Guru pada Domain 4 Tanggungjawab Profesional

\begin{tabular}{|c|c|c|c|c|c|}
\hline KOMPONEN DOMAIN 4 & $\mathbf{Z M}$ & JH & TA & DW & SM \\
\hline Merefleksikan pengajaran & 3 & 3 & 3 & 3 & 3 \\
\hline $\begin{array}{l}\text { Membuat catatan yang akurat (kehadiran siswa, jurnal } \\
\text { pembelajaran, dll) }\end{array}$ & 3 & 3 & 3 & 3 & 3 \\
\hline Berkomunikasi dengan orang tua siswa & 2 & 2 & 2 & 2 & 2 \\
\hline Memberi kontribusi pada sekolah dan dinas pendidikan & 2 & 2 & 2 & 2 & 2 \\
\hline Mengembangkan keprofesian & 2 & 2 & 2 & 2 & 2 \\
\hline Menunjukkan profesionalisme & 3 & 3 & 3 & 3 & 3 \\
\hline
\end{tabular}

Sumber: Data penelitian

Tabel 4 di atas menunjukkan bahwa skor para Guru pada aspek tanggung jawab professional berada pada kategori baik untuk 3 sub-aspek dan berada pada kategori cukup untuk 3sub-aspek, menurut skala evaluasi Charlotte Danielson.

Begitu juga berdasarkan hasil observasi wakil kepala sekolah semua guru mempunyai kinerja yang baik. Adapun kinerja baik dari guru ini diperoleh dari kebiasaan guru yang selalu merefleksikan pengajaran mereka dan juga catatan yang dimiliki oleh guru seperti misalnya jurnal mengajar, absensi siswa.

Namun, meskipun kinerja guru dinyatakan baik, berdasarkan hasil wawancara dengan guru dan kepala sekolah, masih ada beberapa kekurangan. dimana kurangnya komunikasi guru dengan orang tua atau wali murid dalam hal proses pembelajaran, masih ada guru yang belum memberikan kontribusi baik untuk nama sekolah sendiri ataupun untuk dinas pendidikan setempat seperti misalnya guru berprestasi, dan juga guru masih belum menunjukkan perkembangan dalam keprofesiannya seperti misalnya pembuatan PTK, menulis karya ilmiah, menghasilkan karya inovatif baik didalam ataupun diluar pembelajaran.

\section{Pembahasan}

Temuan penelitian ini mendukung penelitian yang dilakukan oleh Tethys Arsynta
(2015) dengan judul "Kinerja Guru Bersertifikat Profesi dalam Pembelajaran di SMK Negeri se-Kota Magelang." Hasilnya menyimpulkan bahwa kinerja guru bersertifikat profesi dalam perencanaan pembelajaran dikategorikan baik; kinerja guru sertifikasi di Gugus Mangga pada komponen pengembangan diri berada pada kriteria kurang baik (Kartomo \& Slameto, 2016). Kinerja mengajar guru kelas $\mathrm{V}$ bersertifikasi di Daerah Binaan 2 Kecamatan Parakan pada bidang Perencanaan dan Pelaksanaan Pembelajaran masuk kategori baik dan sangat baik (Setyowati \& Sulasmono, 2015).

Temuan penelitian menunjukkan sedikit perbedaan dengan penelitian yang dilakukan Tethys (2015), dimana penelitian tersebut menyimpulkan bahwa kinerja guru bersertifikat profesi dalam pelaksanaan pembelajaran dengan sub komponen pengelolaan kelas hanya dikategorikan cukup baik, sub komponen penggunaan metode pembelajaran juga dikategorikan cukup baik, dan begitu pula sub komponen penggunaan media dan sumber belajar dikategorikan cukup baik.

Temuan penelitian ini sama dengan penelitian yang dilakukan oleh Tethys (2015) yang menyimpulkan bahwa kinerja guru bersertifikat profesi dalam pelaksanaan pembelajaran dikategorikan baik. 
Hasil temuan penelitian ini sama dengan hasil penelitian yang dilakukan oleh Suyanti (2009) tentang evaluasi kinerja guru pada sekolah menengah pertama sebagai rintisan sekolah bertaraf internasional di kota Yogyakarta. Hasil penelitian Suyanti menyimpulkan bahwa kompetensi profesional yang diperoleh guru hanya dikategorikan cukup. Sedangkan kompentensi kepribadian, kompetensi pedagogik, dan kompetensi sosial dikategorikan baik.

Khusus tentang kebijakan sertifikasi Guru, penelitian Khodijah (2013) tentang kinerja Guru Madrasah dan Guru Pendidikan Agama Islam pasca sertifikasi di Sumatera Selatan, menunjukkan bahwa tidak terdapat perbedaan dalam kinerja guru setelah menerima tunjangan professional dalam aspek (1) rencana pembelajaran, pelaksanaan, dan asesmen; (2) antara mereka yang tinggal di daerah pedesaan dan di daerah perkotaan; dan (3) antara mereka yang lulus melalui portofolio dan yang melalui PLPG. Dengan kata lain kinerja guru bersertifikasi masih di bawah standar minimum kinerja. Selanjutnya penelitian Kurniawan (2011) berjudul "Implementasi Kebijakan Sertifikasi Guru dalam Rangka Meningkatkan Profesionalitas Guru di Kota Yogyakarta" menyimpulkan bahwa jika dilihat dari segi dampak kebijakan sertifikasi, belum ada peningkatan profesionalitas guru secara signifikan. Sikap para guru dalam menjalankan kebijakan sertifikasi terlihat hanya mengejar kesejahteraan semata, sementara mutu pengajaran kurang mendapat perhatian. Sedang penelitian Yusrizal, dkk (2011) dengan judul "Evaluasi Kinerja Guru Fisika, Biologi, dan Kimia SMA yang sudah lulus sertifikasi” menunjukkan bahwa kinerja guru Fisika, Biologi, dan Kimia SMA yang sudah lulus sertifikasi dan sudah menerima tunjangan belum seluruhnya berkinerja tinggi. Sementara itu penelitian Amat Jaedun (2009) dengan judul "Evaluasi Kinerja Guru Bersertifikat
Profesional" juga menunjukkan bahwa kinerja guru yang telah disertifikasi (guru profesional) tidak menjadi lebih baik bila dibandingkan dengan kinerja guru sebelum disertifikasi. Kinerja guru menurun karena merasa tidak lagi dinilai, dan tidak ada sanksi setelah mendapatkan sertifikasi. Oleh karena itulah perlu dilakukan evaluasi terhadap kinerja guru yang telah disertifikasi tersebut secara berkelanjutan.

\section{SIMPULAN DAN SARAN Simpulan}

Berdasarkan temuan dan pembahasan hasil penelitian evaluasi seperti dipaparkan sebelumnya, dapat disimpulkan empat hal sesuai dengan permasalahan penelitian yang telah dirumuskan yaitu bahwa (1) kinerja guru bersertifikasi di SMP Negeri 3 Salatiga dalam merencanakan dan mempersiapkan pembelajaran masuk dalam kategori baik, (2) kinerja guru bersertifikasi di SMP Negeri 3 Salatiga dalam mengelola kelas termasuk kategori baik, (3) kinerja guru bersertifikasi di SMP Negeri 3 Salatiga dalam berinteraksi dengan siswa saat pembelajaran berlangsung masuk dalam kategori baik, dan (4) kinerja guru bersertifikasi di SMP Negeri 3 Salatiga dalam menunjukkan tanggung jawab profesionalnya sebagai seorang guru dikategorikan cukup baik.

\section{Saran}

Berdasarkan hasil penelitian evaluasi kinerja guru bersertifikasi dengan model Charlotte Danielson seperti dikemukakan diatas, dapat disampaikan saran agar para guru, lebih aktif mengikuti berbagai kegiatan yang berhubungan dengan pengembangan profesi mereka seperti seminar, workshop, pelatihan dan sejenisnya. Guru perlu mengikuti kegiatan seperti ini agar dapat mengembangkan diri dalam meningkatkan keprofesian mereka di dunia pendidikan. Kepala sekolah disarankan untuk mengadakan dan/atau mengikutsertakan para guru agar mengikuti berbagai pelatihan, seminar, workshop yang berhubungan dengan 
Evaluasi Kinerja Guru Bersertifikasi Dengan Model Charlotte Danielson | Wara H. Oktriany, dkk.

upaya peningkatan keprofesian mereka sehingga semua guru dapat memberikan kontribusi prestasi pada sekolah. Sedangkan bagi pengawas sekolah, disarankan untuk memberikan motivasi kepada kepala sekolah dan guru agar guru - guru tidak hanya aktif dalam mengajar saja namun guru - guru perlu mengembangkan diri dalam meningkatkan keprofesionalan mereka di dunia pendidikan.

\section{DAFTAR PUSTAKA}

Agus, M.; Taha, Zainuddin; ide Said DM, H. M.; Saleh Muhammad. 2016. Analysis of Professional Competence of Bahasa Teachers of Senior High School in Jeneponto Regency after Certification. Journal of Language Teaching \& Research . Jan2016, Vol. 7 Issue 1, p66-75

Azwar, Saifuddin. 2012. Reliabilitas dan Validitas. Yogyakarta: Pustaka Belajar.

Danielson, Charlotte. 2007. Enhancing professional practice: A framework for teaching (2nd ed.). Alexandria, Va.: Association for Supervision and Curriculum Development. ISBN 9781416605171.

Danielson, Charlotte. 2009. Implementing the Framework for teaching in Enhancing Professional Practice. Alexandria, Va.: Association for Supervision and Curriculum Development. ISBN 978-14166-0913-3.

Darmini. 2012. "Persepsi Guru Non Sertifikasi terhadap Etos Kerja dan Kinerja Mengajar Guru Sekolah Dasar Bersertifikasi Kecamatan Kandangan". Tesis.

Dharma, Surya. 2005. Manajemen Kinerja : Falsafah, Teori dan Penerapannya. Yogyakarta : Pustaka Pelajar.
Faisa, Ulin. 2015. Evaluasi Implementasi Kebijakan Sertifikasi Guru di Sekolah Dasar Negeri 13 Kota Pontianak. PublikA, Jurnal S-1 Ilmu Administrasi Negara, Volume 4 Nomor 1 Edisi Maret, hal 66-75

Jaedun, Amat. 2009. Evaluasi Kinerja Guru Bersertifikat Profesional.

Kartomo, A. I., \& Slameto, S. (2016). Evaluasi Kinerja Guru Bersertifikasi. Kelola: Jurnal Manajemen Pendidikan, 3(2), 219-229.

Khodijah, Nyayu. 2013. Kinerja guru madrasah dan guru pendidikan agama islam pasca sertifikasi di Sumatera Selatan. Cakrawala Pendidikan, Februari 2013, Th. XXXII, No. 1 (91102)

Kunandar. 2007. Guru Profesional: Implementasi Kurikulum Tingkat satuan Pendidikan (KTSP) dan persiapan menghadapi sertifikasi guru. Jakarta: RajaGrafindo Persada.

Kurniawan, Bachtiar Dwi. 2011. Implementasi Kebijakan Sertifikasi Guru dalam Rangka Meningkatkan Profesionalitas Guru di Kota Yogyakarta. Jurnal Studi Pemerintahan Vol.2 No.2 Agustus 2011 (278-299)

Marwansyah. 2010. Manajemen Sumber Daya Manusia. Bandung: Alfabeta

Muslich, Masnur. 2007. Sertifikasi guru menjadi profesionalisme pendidik. Jakarta : Bumi Aksara.

Parkay, Forrest W. 2011. Menjadi Seorang Guru. Jakarta: PT Indeks.

Payong, Marselus. 2011. Sertifikasi Profesi Guru : Konsep Dasar, Problematika, dan Implementasinya. Jakarta : PT Indeks 
Kelola: Jurnal Manajemen Pendidikan, Vol. 5, No. 1, Januari-Juni 2018

Peraturan Menteri Negara Pendayagunaan Aparatur Negara dan Reformasi Birokrasi Nomor 16 tahun 2009 tentang jabatan Fungsional Guru dan Angka Kredit

Permendiknas No. 41 Tahun 2007 tentang Standar Proses untuk Satuan Pendidikan Menengah

Permendiknas Nomor 16 tahun 2007 tentang Standar Kualifikasi Akademik dan Kompetensi Guru.

Rivai, Veithzal. 2008. Perfomance Appraisal. Jakarta: PT RajaGrafindo Persada.

Sasadara,W.L.; Sulasmono, B.S.; \& Ade Iriani. 2017 Evaluasi Implementasi Kebijakan Pendidikan Inklusi. Kelola: Jurnal Manajemen Pendidikan Vol 4 No 2 hal $1-. .$.

Setiawan Ngadirin.; Dhyah Setyorini; Amanita Novi Yushita. 2009. Audit Kinerja Guru Akuntansi Bersertifikat Di SMK Negeri 2 Kutoarjo Purworejo. Jurnal Pendidikan Akuntansi Indonesia Vol. VII. No. 2 - Tahun 2009

Setyowati, T., \& Sulasmono, B. S. 2015. Evaluasi Kinerja Mengajar Guru Kelas V Bersertifikasi di Daerah Binaan 2 Kecamatan Parakan. Kelola: Jurnal Manajemen Pendidikan, 2(1), 86-98.

Sugiyono. 2014. Metode Penelitian Manajemen. Bandung: Alfabeta

Sugiyono. 2015. Metode Penelitian dan Pengembangan Research and Development. Bandung: Alfabeta.

Sukmadinata, Nana Syaodih. 2012. Metode Penelitian Pendidikan. Bandung: PT Remaja Rosdakarya.

Sulasmono, B.S. \& Tri Sulistyowati. 2016. Context, Input, Process and Product Evaluation of the Inclusive Education Program in Public Elementary School.
Prosiding

ICERI

Yogyakarta

Suyanti. 2009. Evaluasi Kinerja Guru pada Sekolah Menengah Pertama sebagai Rintisan Sekolah Bertaraf Internasional di Kota Yogyakarta;

Suyatno. 2008. Panduan Sertifikasi Guru. Jakarta: PT Indeks

Undang - Undang RI no 14 tahun 2005 tentang Guru dan Dosen

Undang - Undang RI No 20 tahun 2003 tentang Sistem Pendidikan Nasional

Uno, Hamzah B. \& Nina Lamatenggo. 2012. Teori kinerja dan pengukurannya. Jakarta: Bumi Aksara

Viani, Farida. 2015. A Performance Evaluation Model for School Teachers: An Indian Perspective

Wibowo. 2013. Manajemen Kinerja. PT: Raja Grafindo Persada: Jakarta

Widodo, Suparno Eko. 2015. Manajemen Pengembangan Sumber Daya Manusia. Yogyakarta : Pustaka Belajar

Wirawan. 2009. Evaluasi Kinerja Sumber Daya Manusia: Teori Aplikasi dan Penelitian. Jakarta : Salemba Empat.

Yusrizal, Soewarno, S dan Zarlaida Fitri. 2011. Evaluasi Kinerja Guru Fisika, Biologi, dan Kimia SMA yang Sudah Lulus Sertifikasi. Jurnal Penelitian dan Evaluasi Pendidikan; Vol 15, No 2 hal 269-286 